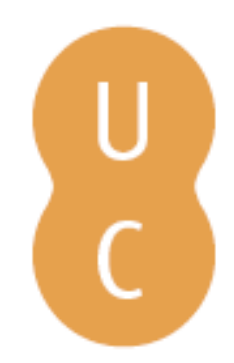

\title{
pombalina
}

\section{Sobre a acentuação paroxítona do vocabulário "Sisifo" na lírica de Camões}

Autor(es): $\quad$ Azevedo Filho, Leodegário A. de

Publicado por: Imprensa da Universidade de Coimbra

URL

persistente: URI:http://hdl.handle.net/10316.2/31258

DOI: $\quad$ DOI:http://dx.doi.org/10.14195/978-989-26-0569-2_42

Accessed : $\quad$ 26-Apr-2023 12:23:06

A navegação consulta e descarregamento dos títulos inseridos nas Bibliotecas Digitais UC Digitalis, UC Pombalina e UC Impactum, pressupõem a aceitação plena e sem reservas dos Termos e Condições de Uso destas Bibliotecas Digitais, disponíveis em https://digitalis.uc.pt/pt-pt/termos.

Conforme exposto nos referidos Termos e Condições de Uso, o descarregamento de títulos de acesso restrito requer uma licença válida de autorização devendo o utilizador aceder ao(s) documento(s) a partir de um endereço de IP da instituição detentora da supramencionada licença.

Ao utilizador é apenas permitido o descarregamento para uso pessoal, pelo que o emprego do(s) título(s) descarregado(s) para outro fim, designadamente comercial, carece de autorização do respetivo autor ou editor da obra.

Na medida em que todas as obras da UC Digitalis se encontram protegidas pelo Código do Direito de Autor e Direitos Conexos e demais legislação aplicável, toda a cópia, parcial ou total, deste documento, nos casos em que é legalmente admitida, deverá conter ou fazer-se acompanhar por este aviso. 


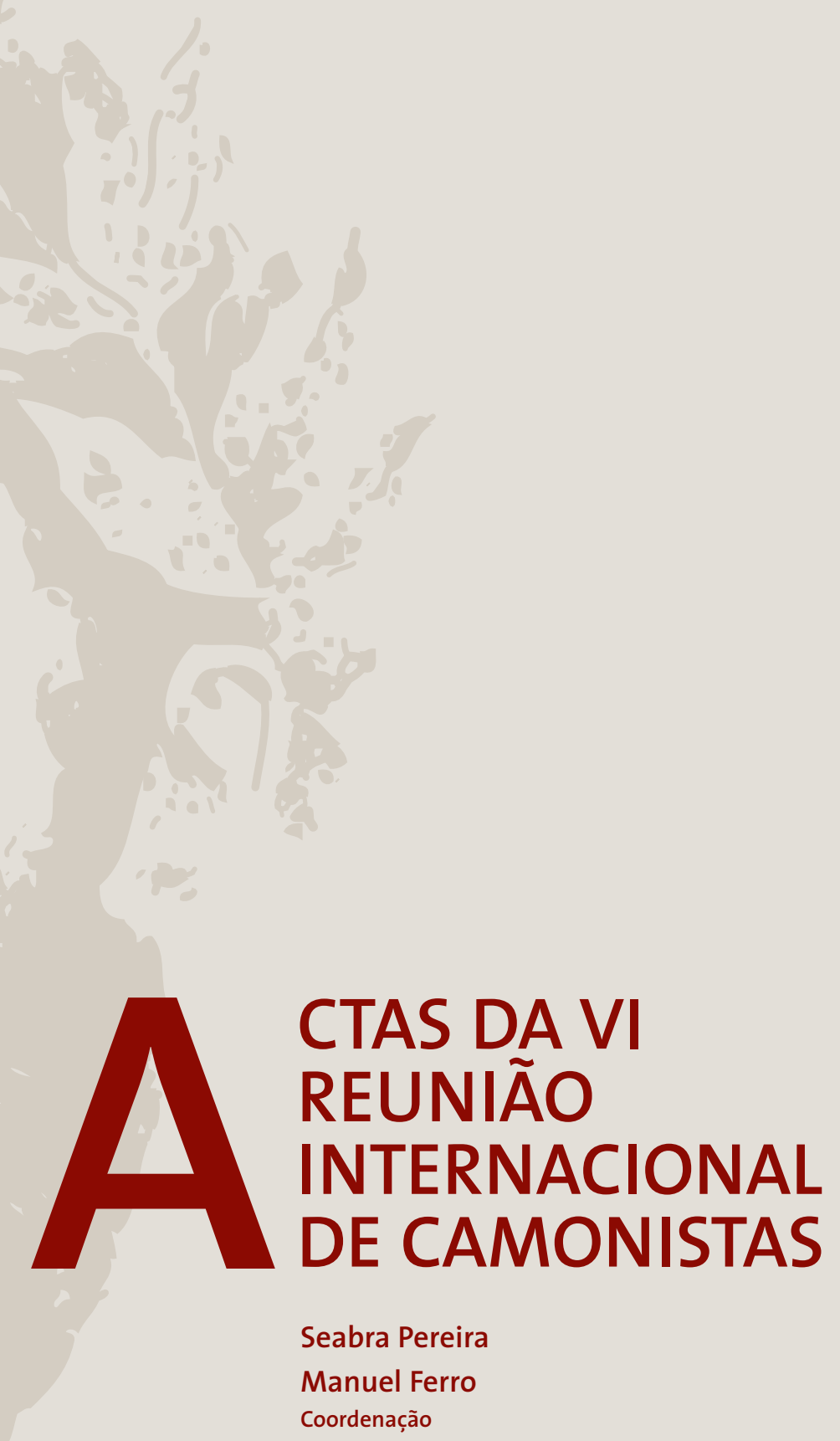


Leodegário A. de Azevedo Filho

Professor Emérito da UERJ e Titular da UFRJ - Rio de Janeiro

\section{SOBRE A ACENTUAÇÁO PAROXÍTONA DO VOCÁBULO "SISIFO" NA LÍRICA DE CAMỐS}

Causou alguma estranheza à crítica despreparada a acentuação paroxítona do nome próprio Sisifo no terceiro volume da nossa edição da Lírica de Camóes, dedicado às Cançóes em seu primeiro tomo - pois o segundo tomo é reservado às Odes -, recentemente publicado pela Imprensa Nacional - Casa da Moeda, de Lisboa. Houve mesmo quem me assegurasse, com habitual autoridade e não menor segurança afirmativa, que o vocábulo devia levar acento na antepenúltima sílaba, como proparoxítono ou esdrúxulo, sendo esta a pronúncia culta de Camóes.

Pois bem, nesta brevíssima comunicação, que apresentamos à VI Reunião Internacional de Camonistas, vamos discutir o assunto, começando pela observaçáo de que a acentuação de nomes próprios na epopeia camoniana, matéria por nós considerada em artigo publicado em Annali dell'Istituto Universitario Orientale, Sezione Romanza, XXXII, 2, 1990, pp. 337-346, está a exigir cuidadoso estudo, em face de algumas ediçóes d'Os Lusiadas e das Rimas com manifestos erros sobre a questão. E aí tratámos dos seguintes casos ortoépicos ou prosódicos: Abila e não Ábila; Amon e não Ámon; Anibal e não Aníbal; Artabro e não Ártabro; Axio e não Áxio; Candace e não Cândace; Centimano e não Centímano; Ciniras e não Cíniras; Cleopatra e não Cleópatra; Climene e não Clímene; Dário e não Dario; Demodoco e não Demódoco; Eolo e não Éolo; Efire e não Éfire; Gedrosia e não Gedrósia; Flafira e não Gláfira; Helicona e não Hélicon; Heliogabalo e não Heliogábalo; Leucothôe e não Leucótoe; Naiade e não Náiade; Pantea e não Pântea; Piróis e não Pírois; Policena e não Polícena; Semele e não Sémele; Taprobana e não Tapróbana; Zopiro e não Zópiro. Ao analisar os casos citados, procurámos mostrar que, no português quinhentista de Camóes, embora a fase fosse de ampla relatinizaçáo do idioma, nem sempre a norma era a de acentuar-se o nome próprio latino à latina, o mesmo ocorrendo com o nome próprio grego, por via do latim.

Antes de nós, como indicámos no artigo citado, trataram do assunto, entre outros, o filólogo português A. Epifânio da Silva Dias, no Registo Philologico da sua conhecida edição d'Os Lusíadas, a propósito do vocábulo Taprobana (paroxítono e não proparoxítono), e o filólogo brasileiro Celso Ferreira da Cunha, em seu artigo "Sobre a pronúncia camoniana de alguns antropônimos", publicado na revista Studia, do Colégio Pedro II, ano XII, no 12, dezembro de 1982, pp. 33-39. Por certo, na epopeia camoniana, em vários casos, a acentuaçáo de nomes próprios de origem greco-latina 
coincide com a prosódia latina, como no caso de Tírio, nome de homem, de grego Tityros, de tityros (bode, carneiro) pelo latim Tityru, neste verso: "Imitando de Títiro as Camenas" (Lus., V, 63). Mas quando não há coincidência, como nos casos acima indicados, tem-se explicado o fenómeno por hiperbibasmo, em função do conceito de liberdade poética, a exemplo do que faziam os próprios escritores latinos com palavras de origem peregrina, usando breves como longas e vice-versa, para atender às necessidades rítmicas do verso. Mas cremos, como o Prof. Doutor Sílvio Elia, eminente linguista brasileiro e sábio camonista, que os escritores deviam seguir o próprio uso da língua nos séculos XV e XVI, cuja prosódia naturalmente se estendeu pelos séculos XVII e XVIII, como igualmente pensa António Houaiss, Mestre em Ecdótica, sem qualquer anormalidade ou desvio de padróes, exactamente porque ainda não havia normas fixas sobre o assunto. Na verdade, tais normas só foram fixadas, e assim mesmo aos poucos, a partir do século XIX, graças ao desenvolvimento dos estudos de gramática histórica ou linguística diacrónica. $\mathrm{E}$ isso não apenas em nomes próprios, mas também em nomes comuns, como archetipo (X, 79) por arquétipo; Capadoces (III, 72) por Capádoces, habitantes da Capadócia (Ásia Menor), modernamente capadócios; epitheto (X, 124) por epiteto; Etiopes (V, 62) por etiopes; e Idolatra (VII, 73; VIII, 85; e X, 147) por idólatra, entre vários outros casos. Em geral, são palavras eruditas, por empréstimo linguístico feito directamente ao latim, mediante certas adaptaçóes fono-morfológicas.

Mas como explicar o desvio da prosódia latina, na passagem directa do latim clássico para o português literário, antes mesmo que os vocábulos entrassem na língua culta falada?

A nosso ver, a explicação é perfeitamente compreensível: o padrão prosódico da língua portuguesa, bem assim o da castelhana, é dado pelo vocábulo paroxítono ou grave, seguido pelo agudo, jamais pelo proparoxítono ou esdrúxulo. Assim, no século de Quinhentos, a pronúncia podia seguir como a do século XV, ou seja, conforme o padrão prosódico geral da língua, muito vezes sem levar em conta a acentuação latina, depois refeita por restauraçáo erudita. Basta ler qualquer autor quinhentista, entre os grandes clássicos da língua, que logo salta aos olhos a penetração, na língua literária, de formas linguísticas colhidas directamente no latim literário, não sendo Camóes uma excepção, mas alto e significativo exemplo. Com efeito, em Sá de Miranda encontram-se Abila $(147,101)$ e Anibal $(105,40$ e 63; e 110, 8), do mesmo modo que em Camóes. E também em autores castelhanos, como indica A. Epifânio da Silva Dias, na p. 340 da edição já aqui referida, de igual maneira fazendo Celso Ferreira da Cunha, em artigo também citado aqui. A propósito, lembra o saudoso Antenor Nascentes, em Dicionário Etimológico da Lingua Portuguesa (Nomes Próprios), que Anibal, como oxítono ou agudo, é a forma encontrada no Cancioneiro Geral, de Garcia de Resende (III, 106; IV, 273; IV, 345; e V, 178); em Camóes (VII, 71; e X, 153); e tal forma linguística chega ao século XVIII, como se pode ver em Tomás António Gonzaga (Marília de Dirceu e mais Poesias, edição do igualmente saudoso M. Rodrigues Lapa). Eis o verso: "Pretendem Anibais honrar a História", conforme se lê na terceira edição da obra citada, da conhecida Colecção de Clássicos Sá da Costa, publicada em Lisboa, 1961, p. 173.

Em nossa edição da Lírica de Camóes, já aqui referida, é claro que temos procurado respeitar a pronúncia da época e do Poeta, revelada pelo ritmo dos versos. Sirvam como simples exemplos, para não alongar os limites desta brevíssima comunicação, 
os seguintes: "Naiades, vós que os rios habitais", p. 453 da nossa edição, embora se leia Náiades em vários editores modernos, o mesmo ocorrendo com Driades, vocábulo paroxítono ou grave, e não proparoxítono, no mesmo soneto, embora em latim fosse Dryade, aparecendo Dríade (proparoxítono) em vários editores modernos. Sobre o assunto, veja-se o comentário que fizemos na p. 463 da nossa edição, primeiro Tomo dos Sonetos, pois desde aí a questão tem causado "erudias estranhezas" em alguns críticos que nada sabem do usus scribendi do Poeta e de sua época. Em verdade pura, na língua de Camóes, como na língua dos demais poetas portugueses e castelhanos da mesma época, não se pode afirmar - a despeito da autoridade com que o fazem - que houvesse uma norma rigorosamente estabelecida para a acentuação dos nomes próprios (e também comuns) de origem latina (ou grega pelo latim), pois tais nomes tanto podiam, dentro de um processo de descodificação e recodificação textual, na passagem do latim literário para o português literário, ajustar-se à prosódia latina, desenvolvendose então formas proparoxítonas, com novos ritmos vocabulares, estranhos ao português arcaico, como podiam aparecer de acordo com o padráo prosódico trocaio ou grave, dominante nas duas línguas românticas, a portuguesa e a castelhana. Há mesmo casos curiosos, como neste verso: "Olha o cabo Asaboro, que chamado" (X, 102), do latim Asaborum, genitivo plural de Asabi, nome do povo, como ensina Antenor Nascentes em seu Dicionário Etimológico, acrescentando que João de Barros, III, 6, 4, tomando o genitivo por um nominativo neutro (em Asaborum promontorium), traduziu por Asaboro, no que foi seguido por Camóes.

Chegamos assim ao verso no 95 da Canção "A instabilidade da Fortuna", em seguida transcrito: "Não te espantes, Sisifo, deste alento". Nem A. Epifânio da Silva Dias, nem Celso Ferreira da Cunha, em textos já aqui referidos, trataram do assunto. Ou seja: da pronúncia Sisifo e não Sísifo, certamente porque o vocábulo não aparece em nenhum dos versos d'Os Lusíadas. Mas o verso lírico acima transcrito claramente revela a pronúncia paroxítona do Sisifo (e não Sisifo), por força da acentuação tónica na sexta sílaba do belo decassílabo. Aliás, sem perceber isso, o erudito Faria e Sousa, em sua conhecidíssima edição, contrariando os manuscritos da época, com evidente propósito de "corrigir" o ritmo do verso camoniano, alterou-lhe arbitrariamente a ordem das palavras: "Sísifo, não te espantes deste alento." E tal emenda "correctiva”, de todo improcedente, além de aparecer na famosa Antologia, de Agostinho de Campos, foi também acolhida na edição chamada crítica de José Maria Rodrigues e Afonso Lopes Vieira, publicada em Coimbra, em 1932.

Como acima se vê, já não basta ficar apenas com a tradição impressa dos textos líricos de Camóes. Será preciso ir aos manuscritos da época, em busca da perdida voz do Poeta, tão estudado e ainda tão pouco conhecido. Queremos dizer: será preciso, urgentemente, reinaugurar a lírica de Camóes, com nova metodologia, pois os caminhos até aqui seguidos, na verdade, induziram os editores a poucos resultados positivos. 